MAMBRÍ, APS; ANDRIOLO, JL; MANFRON, MP; PINHEIRO, SMG; CARDOSO, FL; NEVES, MG. 2018. Yield and composition of lavender essential oil grown in substrate. Horticultura Brasileira 36: 259-264. DOI: http://dx.doi.org/10.1590/S0102-053620180219

\title{
Yield and composition of lavender essential oil grown in substrate
}

\author{
Ana PS Mambrí; Jerônimo L Andriolo; Melânia P Manfron; Suany MG Pinheiro; Francieli L Cardoso; \\ Myriam G Neves
}

Universidade Federal de Santa Maria (UFSM), Santa Maria-RS, Brazil; ana.mambri@gmail.com; jeronimoandriolo@gmail.com; melaniapalermo@gmail.com; suanygp@hotmail.com; agronomyriam@hotmail.com; franci-lc@hotmail.com

\begin{abstract}
The objective of this research was to evaluate the effect of successive harvesting times and shading on the production of biomass, yield and phytochemical composition of essential oil in leaves and inflorescences of soilless grown Lavandula dentata. Plants were grown in pots filled with sand, inside a polyethylene greenhouse, in a closed system at UFSM. Plants were harvested at 150, 213 and 320 days after planting date (DAP) in winter, spring and summer, respectively. At $150 \mathrm{DAP}$, a 50\% shading screen was installed. The experimental design was a randomized $3 \times 2$ factorial in subdivided plots with 36 plants per subplot. Fresh (FM) and dry mass (DM), yield and chemical composition of essential oil in leaves and inflorescences were determined after each harvest date. The essential oil was extracted, using $70 \mathrm{~g}$ fresh mass of leaves and of inflorescences, respectively. Identification and quantification of compounds in the essential oil were determined by gas chromatography/mass spectrometry (GC/MS). The FM of inflorescences was higher on plants harvested 213 DAP grown without shading while of leaves it was higher on plants harvested 320 DAP grown without shading. The yield of the essential oil was higher in the leaves of plants harvested 320 DAP grown without shading. Thirty-one compounds were identified and quantified, being the major ones 1.8 cineol, camphor and linalool, without significant difference among treatments. Three consecutive harvests can be made in August (150 DAP), October (213 DAP) and February (320 DAP) without replacing plants.
\end{abstract}

Keywords: Lavandula dentata, aromatic plant, phytomass, solar radiation.

\section{RESUMO}

Rendimento e composição do óleo essencial de lavanda cultivada em substrato

Avaliou-se o efeito de sucessivas épocas de colheita e do sombreamento na produção de fitomassa, rendimento e composição fitoquímica do óleo essencial de folhas e inflorescências de Lavandula dentata em cultivo fora do solo. As plantas foram cultivadas em vasos preenchidos com areia, no interior de um abrigo de polietileno, em sistema fechado na UFSM. Foram realizadas três coletas sucessivas aos 150, 213 e 320 dias após o plantio (DAP), no inverno, primavera e verão, respectivamente. Aos 150 dias após o plantio, foi instalada tela com $50 \%$ de sombreamento. O delineamento experimental foi fatorial $3 \times 2$ casualizado em parcelas subdivididas com 36 plantas por subparcela. A massa fresca (MF) e seca (MS), o rendimento e a composição química do óleo essencial de folhas e inflorescências foram determinados em cada coleta. O óleo essencial foi extraído utilizando $70 \mathrm{~g}$ de massa fresca de folhas e de inflorescências, respectivamente. A identificação e a quantificação dos compostos no óleo essencial foram determinadas por cromatografia gasosa/espectrometria de massas (GC/MS). A MF das inflorescências foi mais elevada na colheita, aos 213 DAP sem sombreamento, enquanto a MF de folhas foi mais elevada na colheita de 320 DAP sem sombreamento. O rendimento do óleo essencial foi mais elevado nas folhas, aos 320 DAP sem sombreamento. Foram identificados e quantificados 31 compostos, sendo majoritários 1,8 cineol, cânfora e linalol sem diferença significativa entre os tratamentos. Realizando o plantio em substrato no início de março podem ser feitas três colheitas sucessivas em agosto (150 DAP), outubro (213 DAP) e fevereiro (320 DAP) sem substituição das plantas.

Palavras-chave: Lavandula dentata, planta aromática, fitomassa, radiação solar.

\section{Received on July 15, 2016; accepted on January 3, 2017}

$\mathrm{P}$ lants with aromatic and medicinal properties, such as lavenders, have been attracting growing interest in the national market. Their bioactive secondary compounds are used to obtain products with perfumery or therapeutic action. Lavandula dentata, popularly known as French lavender are plants grown commercially for the extraction of essential oil and also employed as ornamentals and for honey production. Lavender has a wide adaptation in diverse climatic and soil conditions, being found in several countries in Europe, the Middle East, Asia and North Africa where it is used as source of raw material in the pharmaceutical, food, cosmetics, aromas and agroindustry (Biasi \& Deschamps, 2009). In Brazil, through technology and innovation for cultivation, it is possible to achieve significant productivity of this species (Silva, 2015).

Several compounds were cited as major components in lavender essential oil in plants grown in Algeria, Saudi Arabia, Spain, Morocco and Turkey: 1,8 cineole, camphor, borneol, fenchol, $\alpha$-pinene, $\beta$-pinene, trans-pinocarol and linalool (Bousmaha et al., 2005). 
Among these, some have antibacterial and antifungal properties (Aly et al., 2013), antioxidants and citotoxicity (Imelouane et al., 2010; Abdel-Hady et al., 2014). The composition and the relative proportion of the individual components constituting the essential oils are not constant, may vary according to the harvest times, the development stage of the plant and the different part of the plant (Bousmaha et al., 2005). According to Zheljazkov et al. (2013), the chemotype of the plant changes according to interactions with the environment such as temperature and solar radiation.

Lavender for essential oil production, in Brazil and other countries, is cultivated mainly in the field, with up to two annual harvests, when there is regrowth, usually made at maximum vegetative plant growth and/or full flowering (McNaughton, 2006). In southern Brazil, the growth and development of plants in conventional cultivation in soil in the winter months suffer negative effects of low temperatures and high rainfall (Alvares et al., 2014). To minimize these effects, the cultivation off-soil and in greenhouse is the alternative that allows the management of environmental conditions such as temperature and solar radiation intensity, as well as the availability of water and nutrients. The greenhouse also allows a better planning of production throughout the year. From the industrial point of view, several harvests of aromatic plants throughout the year are favorable for commercial production of essential oils.

The intensity of solar radiation can affect the growth, yield and composition of lavender essential oils (Zheljazkov et al., 2013). Solar radiation varies naturally throughout the seasons. In the central region of the State of Rio Grande do Sul, global solar radiation intensity is close to $8.4 \mathrm{MJ} \mathrm{m}^{-2}$ day $^{-1}$ in the winter months and can reach values close to $40 \mathrm{MJ} \mathrm{m}^{-2}$ day $^{-1}$ in summer (Alvares et al., 2014). The intensity in winter is in the trophic limit that has been indicated for the summer growing vegetables (FAO, 2013) while that in summer can reduce growth and affect plant physiology because it mainly alters the water potential of the plant. Publications show that the growth of lemon balm (Melissa officinalis) cultivated in soil was favored by shading (Brant et al., 2009) and reduced in basil plants (Ocimum basilicum) grown in pots in the greenhouse (Chang et al., 2008). In both species, shading affected the composition of the oil. No results were found in the literature about the growth and yield of lavender oil at different planting periods through the year nor the effect of solar radiation intensity over these variables.

The objective of this research was to evaluate the effect of successive cropping periods and two intensities of solar radiation in the production of biomass, yield and phytochemical composition of the essential oil of leaves and flowers of Lavandula dentata grown on substrate.

\section{MATERIAL AND METHODS}

The experiment was conducted in a polyethylene greenhouse in the experimental area of Plant Science Department of Federal University of Santa Maria (UFSM) from March 8, 2014 to February 6, 2015. The climate of the region is $\mathrm{Cfa}$, subtropical humid with no defined dry season (Alvares et al., 2014). The global solar radiation and the daily air temperature inside greenhouse were measured by Electronic Recorder (RHT10, Humidity and temperature USB datalogger ${ }^{\circledR}$ and Daqpro 5300 brand Fourier ${ }^{\circledR}$ ). The average daily temperatures were $18.2^{\circ} \mathrm{C}, 19.8^{\circ} \mathrm{C}$ and $25^{\circ} \mathrm{C}$ from planting date until harvest on each planting period: August (T1150DAP), October (T2-213DAP) and February (T3-320 DAP), respectively. The mean solar radiation was $8.84,10.41$ and $17.49 \mathrm{MJ} \mathrm{m}^{-2}$ respectively, in the same periods. For plants, growing under shading conditions, in the $\mathrm{T} 2$ and $\mathrm{T} 3$ seasons, the average temperatures were $21.1^{\circ} \mathrm{C}$ and $27.1^{\circ} \mathrm{C}$ and solar radiation 5.20 and $8.74 \mathrm{MJ} \mathrm{m}^{-2}$, respectively.

The material used for plant cultivation was composed of benches with $0.8 \mathrm{~m}$ height, made up by fiber cement tiles with $3.95 \mathrm{~m}$ in length and $1 \mathrm{~m}$ in width, supported with slope of $1 \%$ on a masonry structure. Tiles were coated with clear low density polyethylene film $(100 \mu \mathrm{m})$. Gullies, $6 \mathrm{~cm}$ high and $18 \mathrm{~cm}$ apart, were filled with medium-sized basaltic stone used in civil construction, with a particle size between 15 and $20 \mathrm{~mm}$. Polypropylene pots (3 liter capacity) were filled with sand particles $\left(>3 \mathrm{~mm}, 1.6 \mathrm{kh} \mathrm{dm}^{-3}\right)$ with water retention capacity of 238 $\mathrm{mL} \mathrm{dm}{ }^{-3}$. These pots were allocated above the gravel, arranged on benches in three rows, $35 \times 30 \mathrm{~cm}$ between rows and vessels in the row, totaling 36 pots per bench, one plant per pot.

Seedlings with a mean height of 15 $\mathrm{cm}$ were purchased locally and planted in pots at a density of nine plants per square meter. The nutrient solution was used for the soil-free cultivation of rosemary, with the following ionic composition, in mmol L-19 9.17 of $\mathrm{NO}_{3}^{-}$; $1.36 \mathrm{NH}_{4}^{+} ; 1.0 \mathrm{H}_{2} \mathrm{PO}_{4}^{-} ; 4.0 \mathrm{~K}^{+} ; 4.46 \mathrm{Ca}^{+2}$; $2.0 \mathrm{Mg}^{+2}$ and 2.0 of $\mathrm{SO}_{4}^{-2}$. Micronutrients were supplied at concentrations of, in $\mathrm{mg} \mathrm{L}{ }^{-1}, 0.03$ of Mo; $0.26 \mathrm{~B}$; $0.06 \mathrm{Cu}$; $0.50 \mathrm{Mn} ; 0.22$ of $\mathrm{Zn}$ and $1.0 \mathrm{mg} \mathrm{L}^{-1}$ of $\mathrm{Fe}$ in the chelated form (Frescura, 2014). Macronutrients were supplied through fertilizers potassium nitrate, monobasic ammonium phosphate, calcium nitrateCalcinit $^{\circledR}$ and magnesium sulfate. The electrical conductivity of this nutrient solution was $1.0 \mathrm{dS} \mathrm{m}^{-1}$ and the $\mathrm{pH}$ was 6,0 .

The nutrient solution was supplied through drip tapes connected to a pump submerged inside the reservoir, activated by a time programmer. For each row of vessels, a drip tape was distributed, with one dripper per vessel with $1.8 \mathrm{~L} \mathrm{~h}^{-1}$. A drainage coefficient of $30 \%$ was used in each fertirrigation and the drained solution was collected and returned to the storage tank, in a closed system. Up to eight 15 -min daily fertirrigations were estimated, taking into account maximum incident solar radiation, maximum potential transpiration of vegetables per unit foliar area (FAO, 2013) and the crop development stage, in order to maintain volume of water available in the substrate always close to that in the maximum water holding capacity.

The electrical conductivity was measured every two days and corrected whenever a variation of $10 \%$ was verified in relation to the initial value $(1.0 \mathrm{dS}$ 
$\mathrm{m}^{-1}$ ), by adding water or aliquots of new nutrient solution, with concentration and volume adjusted to reach the initial value. The $\mathrm{pH}$ was maintained between 5.5 and 6.5 tolerating a deviation of 0.2 units by adding $\mathrm{NaOH}$ or $\mathrm{H}_{2} \mathrm{SO}_{4}$ in the $1 \mathrm{~N}$ concentration as needed. The nutrient solution inside reservoirs was completed whenever the volume reached $50 \%$ of the original volume.

Three harvest periods were compared in winter (T1-150 DAP), spring (T2-213 DAP) and late summer (T3-320 DAP), respectively. Plants were harvested on each period at senescence of the basal leaves. On the first harvest period (T1), all plants of the experimental area were harvested at 150DAP. All secondary stems were pruned in the third stem from the beginning of the stem. Immediately after this first harvest, shading was applied through a black polypropylene screen with $50 \%$ reduction of the global solar radiation, installed at 1.50 meters above the top of plants in 50\% of the internal area of the greenhouse, remaining until the end of experiment. Shaded and no-shaded plants were left to regrow after each harvest. The $\mathrm{T} 2$ and $\mathrm{T} 3$ treatments were harvested at 213 and 320 DAP respectively, according to the same criterion adopted for the first harvest.

The experimental design was randomized plots subdivided in a $3 \times 2$ factorial scheme, the harvest periods $(150,213$ and 320 DAP) in plots and the intensity of solar radiation (without and with shading) in subplots. Each plot consisted of a bench with 36 plants, with four replications. Growth determinations were made on ten plants drawn in the rows, excluding borders.

In each crop the inflorescences were manually separated from leaves and the fresh mass of inflorescences (MFI) and leaves (MFF) were evaluated. After harvest, inflorescence and leaves were dried in a forced circulation oven at $60^{\circ} \mathrm{C}$ until constant mass, obtaining the dry mass of inflorescence (MSI) and leaves (MSF). The fresh mass of the remaining plants in each plot was used to extract the essential oils in the laboratory.

For the extraction of the essential oil, the collected leaves and inflorescences were stored in a freezer at $4 \pm 0.1^{\circ} \mathrm{C}$. Leaves and inflorescences $(70 \mathrm{~g})$ were crushed and deposited in the distillation flask, adding $500 \mathrm{~mL}$ of water and hydrodistilled in Clevenger type graduated apparatus during three hours. The essential oil was separated from the water and dried over anhydrous sodium sulfate and stored at $-4^{\circ} \mathrm{C}$. Analyzes were performed with four replicates.

The essential oil content (\%) was calculated from a ratio between the mass of essential oil and the sample biomass (oil mass/sample mass), while the yield of the essential oil $(\mathrm{g})$ was calculated from the ratio between the mass of oil and the fresh mass of leaves and flowers of the plant (fresh mass x mass oil)/ sample mass $\}$.

Composition of oil was determined by gas chromatography (GC) connected to a flame ionization detector (FID) in a system Agilent Technologies $6890 \mathrm{~N}$ GC-FID ${ }^{\circledR}$, equipped with capillary column HP $5 \mathrm{MS}$ ( $30 \mathrm{~m} \times 0.25 \mathrm{~mm}$, and $0.25 \mathrm{~mm}$ ). Helium was used as the entrainment gas at a flow rate of $1.3 \mathrm{~mL} /$ $\mathrm{min}$. The thermal programmer was 50 $300^{\circ} \mathrm{C}$ at a rate of $5^{\circ} \mathrm{C} / \mathrm{min}$. Duplicates of samples were processed in the same manner. Relative concentrations of the components were calculated based on GC peak areas without use of correction factors. The volume of oil injection was $1 \mu \mathrm{L}$.

GC-MS analyzes were performed on an Agilent Technologies system AutoSystem XL GC-MS operating in mode $\mathrm{EI}$ at $70 \mathrm{eV}$, equipped with a split injector $\left(250^{\circ} \mathrm{C}\right)$. The transfer line temperature was $280^{\circ} \mathrm{C}$. Helium was used at a flow of $\left(1.5 \mathrm{~mL} \mathrm{~min}^{-1}\right)$ equipped with HP 5MS capillary columns $(30 \mathrm{mx}$ $0.25 \mathrm{~mm} ; 0.25 \mathrm{~mm}$ film thickness) and an HP innowax (30 m x $0.32 \mathrm{~mm}$; 0.50 $\mathrm{mm}$ of film thickness). The temperature program was the same as that used for $\mathrm{GC}$ analysis. The volume injected was $1 \mu \mathrm{L}$ of the essential oils. The essential oil components were identified on the basis of the retention index (IR), with data of mass spectra and IR of literature (Adams, 1995).

Data were submitted to analysis of variance and significance of differences between the means determined by the test of Tukey, $5 \%$ probability, using the program SISVAR.

\section{RESULTS AND DISCUSSION}

There was a significant interaction between the three harvesting periods and shading for the evaluated fresh mass (MFI) and dry mass (MSI) characteristics of inflorescences (Table 1). The highest fresh mass means of inflorescences were observed in the harvest done in August before shading. $50 \%$ shading reduced the inflorescence yield by $37 \%$ in the harvest made at 213 DAP and $83 \%$ at 320 DAP.

For fresh leaf mass a significant effect was found among periods, but no significant effect of shading. However, mean dry mass of leaves showed a significant difference in shading and harvest periods. While the fresh leaf mass at 213 DAP and 320 DAP was similar in the no-shaded and shaded plants, dry mass of shaded plants was $36 \%$ and $38 \%$ lower at 213 DAP and 320 DAP, respectively. These results differ from those obtained by Brant $e t$ al. (2009) testing Melissa officinalis, using black mesh with 50\% reduction in solar radiation; they verified that growth was favored in full sun cultivation. However, similar effect was described by Gomes et al. (2009) studying Lippia citriodora with fresh and dry mass reduction by shading of $30 \%, 50 \%$ and $75 \%$. These differences may be associated to the availability of water, since in the soilless cultivation fertigation was adjusted in order to fully meet the diurnal water needs of plants.

The biomass production obtained in this study was superior compared to cultivation data in different regions of Brazil. In Uberlândia, Minas Gerais, the maximum biomass of leaves was $61 \mathrm{~g}$ plant $^{-1}$ in protected cultivation (Silva, 2015), while in the present experiment it reached a total of $910.4 \mathrm{~g} \mathrm{plant}^{-1}$ (Table 1). In the Curitiba region, inflorescences production was $9.08 \mathrm{~g} \mathrm{plant}^{-1}$ in field crop (Masetto, 2009), while in the present research we obtained 42.73 g plant ${ }^{-1}$. These differences can be attributed to the cultivation outside soil, to the harvesting period and to the 
Table 1. Fresh and dry mass $\left(\mathrm{g} \mathrm{plant}^{-1}\right)$ of inflorescences and leaves of Lavandula dentata in three harvest periods with and without shading. Santa Maria, UFSM, 2014.

\begin{tabular}{|c|c|c|c|c|}
\hline \multirow{4}{*}{ Periods (DAP) } & \multicolumn{4}{|c|}{ Inflorescences } \\
\hline & \multicolumn{2}{|c|}{ Fresh mass (g plant $\left.{ }^{-1}\right)$} & \multicolumn{2}{|c|}{ Dry mass (g plant $\left.{ }^{1}\right)$} \\
\hline & \multicolumn{4}{|c|}{ Shading } \\
\hline & $0 \%$ & $50 \%$ & $0 \%$ & $50 \%$ \\
\hline 150 & $33.88 \mathrm{~B}$ & & $7.95 \mathrm{~B}$ & \\
\hline 213 & $89.56 \mathrm{Aa}$ & $56.47 \mathrm{Ab}$ & $29.74 \mathrm{Aa}$ & $0.57 \mathrm{Ab}$ \\
\hline \multirow[t]{2}{*}{320} & $14.29 \mathrm{Ca}$ & $2.39 \mathrm{Bb}$ & $5.04 \mathrm{Ca}$ & $0.63 \mathrm{Ab}$ \\
\hline & \multicolumn{4}{|c|}{ Leaves } \\
\hline 150 & $276.43 \mathrm{~B}$ & & $49.10 \mathrm{C}$ & \\
\hline 213 & $238.66 \mathrm{Ba}$ & $239.27 \mathrm{Ba}$ & $70.30 \mathrm{Ba}$ & $44.80 \mathrm{Bb}$ \\
\hline 320 & 395.31 Aa & $334.34 \mathrm{Aa}$ & $121.30 \mathrm{Aa}$ & $75.40 \mathrm{Ab}$ \\
\hline
\end{tabular}

Means followed by the same uppercase and lowercase letters in columns and lines respectively, do not differ significantly from each other, Tukey, $\mathrm{p}<0.05$ ). $\mathrm{DAP}=$ Days after planting.

Table 2. Oil yield $\left(\mathrm{g}_{\text {plant }}{ }^{-1}\right)$ of leaves and inflorescences of Lavandula dentata in three harvest periods with and without shading. Santa Maria, UFSM, 2014.

\begin{tabular}{lcccc}
\hline & \multicolumn{5}{c}{ Yield $\left(\right.$ g plant $\left.^{-1}\right)$} \\
\cline { 2 - 5 } Periods (DAP) & \multicolumn{4}{c}{ Inflorescences } \\
\cline { 2 - 5 } & \multicolumn{5}{c}{ Shading } \\
\cline { 2 - 5 } & $\mathbf{0 \%}$ & $\mathbf{5 0 \%}$ & $\mathbf{0 \%}$ & $\mathbf{5 0 \%}$ \\
\hline 150 & $0.38 \mathrm{~A}$ & - & $0.52 \mathrm{C}$ & - \\
213 & $0.60 \mathrm{Aa}$ & $0.18 \mathrm{Ab}$ & $1.14 \mathrm{Ba}$ & $0.61 \mathrm{Bb}$ \\
320 & $0.15 \mathrm{Aa}$ & $0.01 \mathrm{Bb}$ & $2.40 \mathrm{Aa}$ & $1.57 \mathrm{Ab}$ \\
\hline
\end{tabular}

Means followed by same uppercase and lowercase letters in columns and lines respectively, do not differ significantly from each other, Tukey, $\mathrm{p}<0.05$ ).

harvesting of several harvests during the year.

The essential oil yield of the fresh plant parts including leaves and inflorescences, varied depending on the harvesting periods and shading (Table 2). The leaves presented higher yields than inflorescences, both in the no-shaded and shaded condition. These results differ from those found by Touati et al. (2011) in Tunisia, with the same species and stage of development, where the yield of inflorescences was $32.4 \%$ higher than that of leaves. This difference indicates that plants of the same species, grown in different regions may present different results in the accumulation of aromatic compounds.

The yield of leaf essential oil was higher in the harvested crop at 320 days after planting $\left(2.4 \mathrm{~g} \mathrm{plant}^{-1}\right)$ followed by 213 DAP $\left(1.14 \mathrm{~g} \mathrm{plant}^{-1}\right)$ and 150 DAP $\left(0.52 \mathrm{~g} \mathrm{plant}^{-1}\right)$. Shading reduced the oil yield by $46.5 \%$ and $31.6 \%$ in the periods 213 DAP (in spring) and 320 DAP (summer), respectively. Results from literature on the effect of shading on the production of essential oil showed that each species reacts differently. Reduced levels of solar radiation increase essential oil yield in basil plants (Ocimum gratissimum) (AdeAdemilua et al., 2013) and pariparoba (Pothomorphe umbellate) (Mattana et al., 2010) while decrease in peppermint (Mentha arvensis) (Chagas et al., 2013) and herb-copaiba (Otacanthus azureus) (Serudo et al., 2013). The results of this work indicate that Lavandula dentata can be included in the second group.

The highest flower yield was obtained at 213 DAP (spring). At 320 DAP (summer) there was a $25 \%$ reduction in essential oil yield. This reduction is attributed to the lower number of inflorescences at that time as well as to a higher proportion at the senescence stage at harvest time (data not shown). The highest content of $L$. dentata oil in inflorescences at the bud stage has been demonstrated in literature (Masetto et al., 2011). Effect of temperature and stage of development of Lavandula angustifolia inflorescences on oil yield was also observed by Hassiotis et al. (2014). In addition to this quantitative variation, the results also showed a qualitative variation between the essential oils of the two parts of the evaluated plant. These differences may be adaptive responses to ecological requirements. The results indicated that temperature and solar radiation increase the accumulation of volatile compounds. The same was found in research done with Lippia alba (Barros et al., 2009) and Salvia officinalis (Verma et al., 2015) where results showed that the harvest period during the year affected yield and quality of essential oil.

In GC-MS chromatographic analyzes all 31 constituents were identified representing $96-95 \%$ of the total essential oil in inflorescences and plant leaves (Table 3). In leaves the major constituents were 1,8 (38.57 to $41.09 \%$ ), linalool (10.56\% to $15.62 \%)$, camphor $(9.32 \%$ to $10.43 \%)$ and sabinene $(3.91 \%$ to $5.61 \%$ ). In inflorescences, the main constituents were 1,8 cineol $(32.48 \%$ to $40.65 \%)$, camphor $(18.32 \%$ to $25.14 \%)$, linalool $(7.22 \%$ to $11.59 \%)$ and fenchone $(5.72 \%)$. The contents of the constituents found in this work differ from those found in literature, which also vary among $L$. dentata plant-producing regions. In Algeria, the major compounds were 1,8-cineol, $\beta$-pinene, trans-pinocarveol and linalool (Bousmaha et al., 2005). In Morocco, the relative concentrations of betapinene, mirthenol and alpha-pinene were higher (Imelouane et al., 2010), while in Egypt other major constituents were found, as menta-1,5-dien-8-ol, caryophyllene, guiaol (Abdel-Hady et al., 2014). In this work some of these compounds are present in small amounts and others have not been found. These differences probably reflect the differentiated physiological responses of plants to conditions in the environment where they were grown, resulting in variability in phytochemical content.

There was variation in the 
Table 3. Chemical composition of the volatile oil of Lavandula dentata in three harvest periods (DAP) with and without shading. Santa Maria, UFSM, 2014.

\begin{tabular}{|c|c|c|c|c|c|c|c|c|c|c|c|}
\hline \multirow{3}{*}{ Constituent } & \multirow{3}{*}{$\mathbf{R I}^{\mathbf{a}}$} & \multicolumn{5}{|c|}{ Inflorescences } & \multicolumn{5}{|c|}{ Leaves } \\
\hline & & \multirow{2}{*}{150} & \multicolumn{2}{|c|}{213} & \multicolumn{2}{|c|}{320} & \multirow{2}{*}{150} & \multicolumn{2}{|c|}{213} & \multicolumn{2}{|c|}{320} \\
\hline & & & $0 \%$ & $50 \%$ & $0 \%$ & $50 \%$ & & $0 \%$ & $50 \%$ & $0 \%$ & $50 \%$ \\
\hline$\alpha$-tujone & 930 & 0.15 & 0.09 & 0.24 & 0.18 & 0.21 & 0.23 & - & - & 0.09 & 0.11 \\
\hline$\alpha$-pinene & 939 & 3.07 & 3.01 & 2.98 & 3.25 & 3.19 & 2.98 & 3.49 & 3.51 & 2.78 & 2.81 \\
\hline camphene & 953 & 1.26 & 1.13 & 1.37 & 0.98 & 1.07 & 0.15 & 0.16 & 0.24 & 0.14 & 0.32 \\
\hline sabinene & 976 & 4.09 & 3.75 & 3.91 & 4.17 & 4.25 & 5.37 & 3.94 & 5.61 & 4.35 & 3.91 \\
\hline$\beta$-pinene & 980 & 0.85 & 0.82 & 0.89 & 0.79 & 0.80 & 0.54 & 0.29 & 0.53 & 0.18 & 0.25 \\
\hline mircene & 991 & 0.13 & - & 0.07 & 0.10 & 0.19 & 1.09 & 1.03 & 1.48 & 0.75 & 0.86 \\
\hline limonene & 1031 & 1.45 & 1.39 & 1.62 & 1.35 & 1.58 & 0.12 & 0.10 & 0.17 & 1.48 & 1.93 \\
\hline 1,8-cineole & 1033 & 37.64 & 35.01 & 40.65 & 32.48 & 36.27 & 41.09 & 38.57 & 40 & 39 & 40.20 \\
\hline$\gamma$-terpinene & 1062 & 1.03 & 0.98 & 1.01 & 1.04 & 1.11 & 0.41 & 0.39 & 0.47 & 0.84 & 0.96 \\
\hline $\begin{array}{l}\text { cis sabinene } \\
\text { hydrate }\end{array}$ & 1068 & 0.85 & 0.79 & 0.56 & 0.63 & 0.78 & 0.07 & 0.11 & 0.15 & - & 0.09 \\
\hline $\begin{array}{l}\text { cis-linalool } \\
\text { oxide }\end{array}$ & 1074 & - & 0.08 & 0.13 & 0.09 & 0.12 & - & - & - & 0.16 & 0.27 \\
\hline fenchone & 1087 & 5.71 & 5.69 & 5.78 & 5.71 & 5.74 & 3.09 & 3.12 & 3.78 & 4.13 & 4.46 \\
\hline terpinolene & 1088 & 0.49 & 0.23 & 0.48 & 0.17 & 0.19 & 1.58 & 1.38 & 1.49 & 1.61 & 1.73 \\
\hline linalool & 1098 & 10.05 & 8.17 & 11.59 & 10.91 & 7.22 & 15.04 & 14.97 & 15.60 & 10.50 & 13.20 \\
\hline fenchol & 1112 & 2.39 & 2.12 & 3.28 & 2.46 & 3.04 & 2.76 & 3.01 & 3.10 & 1.89 & 2.14 \\
\hline canphor & 1143 & 18.32 & 18.95 & 25.14 & 18.58 & 21.73 & 9.86 & 9.32 & 10.40 & 10.10 & 10.30 \\
\hline borneol & 1165 & 0.62 & 0.61 & 0.78 & 0.31 & 0.92 & 0.19 & - & - & 0.07 & 0.12 \\
\hline lavandulol & 1167 & 0.07 & 0.13 & 0.25 & 0.69 & 0.71 & - & 0.41 & 0.58 & - & 0.16 \\
\hline 4-terpineol & 1177 & 1.24 & 1.05 & 1.18 & 1.50 & 1.09 & 3.87 & 2.93 & 3.09 & 2.46 & 2.67 \\
\hline$\alpha$-terpineol & 1189 & 2.98 & 3.14 & 2.96 & 2.96 & 3.05 & 1.62 & 0.98 & 1.07 & 1.95 & 2.04 \\
\hline verbenone & 1204 & 0.17 & - & 0.11 & 0.11 & - & 0.14 & 0.20 & 0.27 & - & - \\
\hline \multicolumn{2}{|l|}{ Monoterpene (\%) } & 92.56 & 86.32 & 100 & 88.46 & 93.26 & 82.46 & 84.40 & 91.54 & 82.48 & 86.49 \\
\hline linalool acetate & 1257 & 0.12 & - & - & - & - & 1.96 & 0.87 & 2.15 & 0.11 & 3.09 \\
\hline lavandulil acetate & 1289 & 1.03 & 0.94 & 1.47 & 1.47 & 0.87 & 0.51 & - & 0.73 & - & 0.86 \\
\hline geranil acetate & 1383 & - & & - & - & 0.01 & 0.07 & - & - & 0.13 & 0.18 \\
\hline$\beta$-cariofilene & 1418 & 0.13 & - & 0.24 & 0.24 & 0.26 & 0.24 & - & 0.08 & 0.01 & 0.27 \\
\hline farnesene & 1420 & 0.71 & 0.56 & 0.49 & 0.49 & 0.75 & 1.48 & 1.56 & 0.97 & 1.32 & 1.61 \\
\hline germacrene D & 1480 & 0.03 & - & - & - & 0.11 & - & - & - & 0.18 & 0.24 \\
\hline isoval lavandulil & 1510 & 0.25 & 0.47 & 0.73 & 0.73 & 0.78 & 0.75 & 0.63 & 1.09 & 0.21 & 1.27 \\
\hline cariofilene oxyde & 1581 & 0.17 & 0.17 & 0.23 & 0.23 & 0.19 & 3.12 & 2.76 & 2.81 & 2.40 & 3.08 \\
\hline cadinool & 1640 & 2.05 & 2.14 & 1.84 & 1.84 & 2.03 & 0.15 & 0.09 & 0.34 & - & 0.63 \\
\hline$\alpha$-bisabolol & 1683 & - & 0.15 & - & - & - & 1.37 & - & 0.16 & 0.05 & 0.24 \\
\hline \multicolumn{2}{|c|}{ Sesquiterpenes (\%) } & 4.49 & 4.28 & 5 & 5 & 5 & 8.28 & 5.91 & 8.17 & 4.36 & 11.23 \\
\hline
\end{tabular}

${ }^{a}$ Retention indices from literature (Adams, 1995).

composition and proportion between leaves and inflorescences, standing out the camphor, which was reduced to approximately half and linalol, which was superior in leaves. Differences in composition and proportion of the chemical constituents in the essential oil by the luminosity conditions confirm observations of Mattana et al. (2010) who showed that, although the concentration of the major compound trans-nerolidol is reduced in shaded environments, the yield of the essential oil was favored.

The results indicate that cultivation outside soil can be an alternative for production of lavender biomass in the southern region of Brazil. Several 
harvests throughout the year are possible without replacing plants, in protected crop structures with high transmissivity to solar radiation. And both artificial shading and other factors that reduce transmissivity of the cover material should be avoided because they reduce inflorescence yield and oil yield. For industrial scale oil production purposes, green mass production schedules can be envisaged in order to extend the industrial processing period during the year. We concluded that, planting in the beginning of March, three consecutive harvests can be made in August (150 DAP), October (213 DAP) and February (320 DAP).

\section{REFERENCES}

ABDEL-HADY, NM; ABDALLAH, GM; IDRIS, NF. 2014. Phytochemical studies and in vivo antioxidant activity of two Lavandula species (Lamiaceae) against streptozotocin induced oxidative stress in albino rats. Journal of Biomedical and Pharmaceutical Research 3: 30-40.

ADAMS, RP. 1995. Identification of essential oil components by gas chromatography/mass spectroscopy. Illinois: Allured Publishing Corporation. 469p.

ADE-ADEMILUA, EO; OBI, HO; CRAKER, LE. 2013. Growth and essential oil yield of African Basil, Ocimum gratissimum, under light and water stress. Journal of Medicinally Active Plants 1: 143-149.

ALVARES, CA; STAPE, JL; SENTELHAS, PC; GONÇALVES, JLM; SPAROVEK, G. 2014. Koppen's climate classification map for Brazil. Meteorologische Zeitschrift 22: 711-728.

ALY, MM; AL-GHAMDI, M; BAFEEL, SO; KHEDR, AM. 2013. Antimicrobial qctivities and phytochemical analysis of the essential oil of Lavandula dentata and Plectranthus tenuiflorus, collected from Al Baha region, Saudi Arabia. Life Science Journal 10: 3302 3309.

BARROS, FMC; ZAMBARDA, EO;
HEINZMANN, BM. 2009. Variabilidade sazonal e biossíntese de terpenóides presentes no óleo essencial de Lippia alba (Mill.) N. E. Brown (Verbenaceae). Química Nova 32: 861-867.

BIASI, LA; DESCHAMPS, C. 2009. Plantas aromáticas: do cultivo à produção de óleo essencial. Curitiba: Layer Studio Gráfico e Editora Ltda. 160p.

BOUSMAHA, L; BEKKARA, FA; TOMI, F; CASANOVA, J. 2005. Advances in the chemical composition of Lavandula dentata $\mathrm{L}$. essential oil from Algeria. Journal of Essential Oil Research 17: 292-295.

BRANT, RS; PINTO, JEBP; ROSA, LF; ALBUQUERQUE, CJB; FERRI, PH; CORREAA, RM. 2009. Crescimento, teor e composição do óleo essencial de melissa cultivada sob malhas fotoconversoras. Ciência Rural 39: 1401-1407.

CHAGAS, JH; PINTO, JEBP; BERTOLUCCI, SKV; COSTA, AG; JESUS, HCR; ALVES, PB. 2013. Produção, teor e composição química do óleo essencial de hortelã-japonesa cultivada sob malhas fotoconversoras. Horticultura Brasileira 31: 297-303.

CHANG, X; ALDERSON, PG; WRIGHT, CJ. 2008. Solar irradiance level alters the growth of basil (Ocimum basilicum L.) and its content of volatile oils. Environmental and Experimental Botany 63: 216-223.

FAO Food and Agriculture Organization of the United Nations. 2013, 28 de março. Good agricultural practices for greenhouse vegetable crops. Available in: http://www.fao. org/3/a-i3284e.pdf

FRESCURA, VDS. 2014. Parâmetros fitoquímicos, genotóxicos e de crescimento de alecrim (Rosmarinus officinalis L.) em diferentes salinidades e doses de nitrogênio. Santa Maria: UFSM. 113p (Tese doutorado).

GOMES, PA; SOUZA, MF; JÚNIOR, ITS; JUNIOR, WGOC; FIGUEIREDO, LS; MARTINS, ER. 2009. Influência do sombreamento na produção de biomassa, óleo essencial e quantidade de tricomas glandulares em cidrão (Lippia citriodora Lam.). Biomas 22: 9-14.

HASSIOTIS, CN; NTANA, F; LAZARI, DM; POULIOS, S; VLACHONASIOS, KE. 2014. Environmental and developmental factors affect essential oil production and quality of Lavandula angustifolia during flowering period. Industrial Crops and Products 62:
359-366.

IMELOUANE, B; ELBACHIRI, A; WATHELET, JP; DUBOIS, J; AMHAMDI, H. 2010. Chemical composition, cytotoxic and antioxidant activity of the essential oil of Lavandula dentata. World Journal of Chemistry 5: 103-110.

MASETTO, MAM. 2009. Ácido giberélico e extrato de alga marinha na produtividade e composição do óleo essencial de lavanda (Lavandula dentata L.). Curitiba: UFPR. 96p (Dissertação mestrado).

MASETTO, MAM; DESCHAMPS, C; MÓGOR, AF; BIZZO, HR. 2011. Teor e composição do óleo essencial de inflorescências e folhas de Lavandula dentata $\mathrm{L}$. em diferentes estádios de desenvolvimento floral e épocas de colheita. Revista Brasileira de Plantas Medicinais 13: 413-421.

MATTANA, RS; VIEIRA, MAR; MARCHESE, JA; MING, LC; MARQUES, MOM. 2010. Shade level effects on yield and chemical composition of the leaf essential oil of Pothomorphe umbellata (L.) Miquel. Scientia Agricola 67: 414-418.

MCNAUGHTON, V. 2006. Lavender: the growers guide. Portland: Timber Press. 192p.

SERUDO, RN; ASSIS, IM; KLEHM, CS; SILVA, JF; FLORENCIO, V. 2013. Acúmulo de matéria seca e rendimento de óleo da planta Otacanthus azureus em função da luminosidade e adubação nitrogenada. Scientia Plena 9: 110-119.

SILVA, SM. 2015. Sistemas agrícolas e adubação na biomassa e óleo essencial de lavanda (Lavandula dentata L.). Uberlândia: UFU. $111 \mathrm{p}$ (Tese doutorado).

TOUATI, B; CHOGRANI, H; HASSEN, I; BOUSSAID, M; TOUMI, L; BRAHIM, NB. 2011. Chemical composition of the leaf and flower essential oils of Tunisian Lavandula dentata $\mathrm{L}$. (Lamiaceae). Chemistry \& Biodiversity 8: 1560-1569.

VERMA, RS; PADALIA, RC; CHAUHAN, A. 2015. Harvesting season and plant part dependent variations in the essential oil composition of Salvia officinalis L. grown in northern India. Journal of Herbal Medicine 5: $165-171$.

ZHELJAZKOV, VD; CANTRELL, CL; ASTATKIE, T; JELIAZKOVA, E. 2013. Distillation time effect on lavender essential oil yield and composition. Journal of Oleo Science 62: 195-199. 